Yoichi Kawanishi • Shoji Harada • Hirokazu Tachikawa

Takehito Okubo • Hiroyasu Shiraishi

\title{
Novel polymorphisms of the AP-2 gene (6p24): Analysis of association with schizophrenia
}

Received: July 26, 1999 / Accepted: September 10, 1999

\begin{abstract}
The transcription factor activator protein $2(A P$ 2) gene is a possible candidate gene for schizophrenia, since it maps near D6S470, a marker on chromosome 6p24 that provided evidence of linkage to schizophrenia. In the present study we analyzed the promoter region and the whole coding region of the human $A P-2$ gene in order to identify genetic variations that may lead to the modification of $A P-2$ expression or the alteration of protein function, contributing to schizophrenia or particular schizophrenic phenotypes. Genomic DNA was isolated from the whole blood samples of 87 unrelated schizophrenics and 100 healthy controls. Polymerase chain reaction (PCR) was performed, using 15 primer sets that spanned the promoter region and the whole coding region, and amplified products were screened by single-strand conformational polymorphism (SSCP) analysis. Aberrant SSCP patterns were analyzed by direct sequencing. Three novel polymorphisms were found in the promoter region; two relatively common $(-90 \mathrm{G} \rightarrow \mathrm{C},-803 \mathrm{G} \rightarrow \mathrm{T})$ and one rare $(-1769 \mathrm{G} \rightarrow \mathrm{A})$. Polymorphic status at both loci suggested strong linkage disequilibrium between the $-90 \mathrm{G}$ and $-803 \mathrm{G}$ alleles, and between the $-90 \mathrm{C}$ and $-803 \mathrm{~T}$ alleles. Although no significant differences in genotypic and allelic frequencies at the -90 and -803 loci were found between patients and controls, significant differences in the distribution of genotypes at the $-90(P=0.008)$ and $-803(P=0.037)$ loci were observed in patients with an episodic course compared with controls. However, the difference for the -803 locus was not significant after Bonferroni correction for multiple comparisons. Our data provided no direct evidence of an association between schizophrenia and the polymorphisms of the $A P-2$ gene, although the positive result at the -90 locus
\end{abstract}

Y. Kawanishi $(\triangle) \cdot$ H. Tachikawa $\cdot$ H. Shiraishi

Department of Psychiatry, Institute of Clinical Medicine, University of Tsukuba, 1-1-1 Tennoudai, Tsukuba, Ibaraki 305-8575, Japan

Tel. +81-298-53-3274; Fax +81-298-53-5225

e-mail: qb2y-kwns@asahi-net.or.jp

S. Harada $\cdot$ T. Okubo

Institute of Community Medicine, University of Tsukuba, Tsukuba, Japan in schizophrenics with an episodic course is potentially interesting.

Key words Activator protein 2 - Association - Polymorphism - Schizophrenics · Linkage disequilibrium · Episodic course

\section{Introduction}

Schizophrenia is thought to be a multifactorial disease. Twin, family, and adoption studies have consistently revealed that genetic factors are involved in this disease (Gottesman 1994). A number of recent linkage studies have suggested the presence of schizophrenia susceptibility loci on chromosome 6p24-21 (Antonarakis et al. 1995; Moises et al. 1995; Schwab et al. 1995; Straub et al. 1995; Wang et al. 1995; Schizophrenia Linkage Collaborative Group for Chromosomes 3, 6 and 8 1996). Integrated physical maps of this region have been constructed to facilitate the identification of candidate genes for schizophrenia, and a large number of genes have been mapped (Davies et al. 1995; Olavesen et al. 1995; Olavesen et al. 1997). Studies of the spinocerebellar ataxia type 1 (SCA1) gene, mapped to chromosome $6 \mathrm{p} 23$, were not consistent with regard to its association with schizophrenia (Wang et al. 1996; MorrisRosendahl et al. 1997). As the chromosomal markers spanned a relatively wide region on the short arm of chromosome 6 , further studies of this region are required to investigate other candidate genes involved in schizophrenia.

The transcription factor activator protein $2(A P-2)$ gene may be a possible candidate gene for schizophrenia, as it mapped near the marker, D6S470, on chromosome 6p24 (Davies et al. 1995; Olavesen et al. 1997) that provided evidence of linkage to schizophrenia (Schwab et al. 1995; Straub et al. 1995). AP-2 regulates the expression of genes required for the development of tissues of ectodermal origin, such as neural crest, brain, and skin (Mitchell et al. 1991; Williams and Tjian 1991a,b). AP-2 binds as a 
homodimer to the consensus recognition sequence GCCNNNGGC, which is an important cis-regulatory element for a variety of genes, including proenkephalin (Hyman et al. 1989), presenilin-2 (Pennypacker et al. 1998), $\beta_{1}$-adrenergic receptor (Okawa et al. 1998), synapsin II (Petersohn et al. 1995), $\alpha 3$ nicotinic receptor subunit (Fornasari et al. 1997), dopamine D1 receptor (Minowa et al. 1992), dopamine $\beta$-hydroxylase (Kim et al. 1998), phenylethanolamine $N$-methyltransferase (Ebert et al. 1998), metallothionein $\mathrm{II}_{\mathrm{A}}$ (Imagawa et al. 1987), keratin (Leask et al. 1991), and AP-2 (Bauer et al. 1994).

The modification of AP-2 expression or the alteration of protein function due to mutations of the $A P-2$ gene may contribute to susceptibility to schizophrenia. In this study, we investigated genetic variations in the promoter region and the coding region of the human AP-2 gene. We also conducted a case-control study to explore the association between polymorphisms in the $A P-2$ gene and schizophrenia, including the subtypes and course specifiers in the $D i$ agnostic and Statistical Manual of Mental Disorders (DSM)-IV (American Psychiatric Association 1994).

\section{Materials and methods}

\section{DNA samples}

Written informed consent, according to research protocols approved by the Ethics Committee of Tsukuba University, was obtained from 87 unrelated schizophrenics consisting of 53 men (mean age, $46.3 \pm 12.7$ years; mean age at onset, $25.7 \pm 7.6$ years) and 34 women (mean age, $47.3 \pm 16.3$ years; mean age at onset, $27.7 \pm 10.7$ years) who met the DSM-IV criteria for schizophrenia (American Psychiatric Association, 1994). The subtype and course specifier for each patient had been determined with the DSM-IV before the genomic DNA analysis in this study was performed.

The controls consisted of 100 unrelated healthy volunteers ( 30 men; mean age, $32.1 \pm 11.4$ years and 70 women; mean age, $43.1 \pm 12.0$ years) who were hospital employees living in the same area as the patients. All patients and controls were ethnically Japanese. Genomic DNA was prepared from whole blood samples collected in disodium ethylenediaminetetraacetic acid (EDTA; $3 \mathrm{mg} / \mathrm{l}$ ). Genomic DNA was extracted by the sodium iodide method (DNA Extractor WB Kit; Wako Pure Chemical Industries, Tokyo, Japan).

\section{Polymerase chain reaction (PCR) conditions}

The nucleotide sequence and the genomic structure of the human $A P-2$ gene have been reported previously, and the nucleotide sequence numbering used in this study was based on that in a previous report (Bauer et al. 1994). The mature $A P-2$ mRNA is spliced from seven exons distributed over a region of $18 \mathrm{~kb}$ of genomic DNA, and an inhibitory AP-2 protein, designated AP-2B, is generated by alternative usage after the fifth exon (Bauer et al. 1994).
The promoter of the $A P-2$ gene contains three AP-2 binding sites (nucleotides -622 to $-614,-425$ to $-417,-385$ to -378 ), an NF-1 binding site (nucleotides -365 to -353 ), an octamer binding site (nucleotides -339 to -330 ), a CT-rich repetitive element (nucleotides -240 to -103 ) (Bauer et al. 1994; Creaser et al. 1996), and a potential binding site for transcription factor NF-KB (nucleotides -1827 to -1818 ) (Baeuerle 1991). Fifteen sets of PCR primers were prepared to produce fragments covering these motifs and the CT-rich repetitive element in the promoter region, and the whole coding region, including the AP-2B-specific region, and all of the exon-intron boundaries of the $A P-2$ gene (Table 1). The $5^{\prime}$-terminus of each primer, except for the AP2STRPR primer, was labeled with indodicarbocyanine fluorescent dye (Pharmacia Biotech, Uppsala, Sweden) to perform fluorescence-based single-strand conformational polymorphism (SSCP) analysis. PCR was performed as reported previously (Kawanishi et al. 1998), with a minor modification: demethyl sulfoxide (final concentration, 5\%) was added to the PCR reaction mixture for two primers sets; AP2PMF and AP2PMR, and AP2EX4PF and AP2EX4PR primers.

Single-strand conformational polymorphism (SSCP) analysis

Fluorescence-based SSCP analysis was performed as reported previously (Kawanishi et al. 1998), with slight modifications. Polyacrylamide gels (PAG) used were 7\% (49:1, acrylamide: bisacrylamide ratio) or 10\% (99:1, acrylamide: bisacrylamide ratio) containing $0.5 \times$ Tris-Borate-EDTA buffer, or 7\% (49:1, acrylamide: bisacrylamide ratio) containing $0.5 \times$ Tris-Borate-EDTA buffer and $10 \%$ glycerol.

\section{PCR product sequencing}

PCR products showing altered band patterns by SSCP analysis were purified by centrifugation, using Microcon tubes (Amicon, Danver, MA, USA). DNA sequences of PCR products were directly determined from both directions, using a cycle sequencing system (Dye Terminator Cycle Sequencing Ready Reaction and ABI PRISM 310 Genetic Analyzer; Perkin-Elmer, Norwalk, Conn, USA).

\section{Restriction enzyme assay}

Restriction fragment-length polymorphism (RFLP) analysis was performed, using a commercially available restriction enzyme according to the manufacturer's recommendations (NIPPON GENE, Tokyo, Japan). Digested products were visualized by electrophoresis in $2 \%$ agarose gels after ethidium bromide staining.

\section{Statistical analysis}

Deviation of the genotype counts from Hardy-Weinberg equilibrium was tested using $\chi^{2}$ test for goodness of fit. 
Table 1. PCR primers for amplification of the promoter region and whole coding region of the human $A P-2$ gene

\begin{tabular}{|c|c|c|c|c|c|}
\hline $\begin{array}{l}\text { Primer } \\
\text { name }\end{array}$ & Primer sequence & Primer position & Region & PCR product (bp) & $\begin{array}{l}\text { Annealing } \\
\text { temperature }\end{array}$ \\
\hline AP2PUF & $\begin{array}{l}\text { 5'-GAATTGTGCTCAGTTCAGGTAG } \\
5^{\prime} \text {-TCATCTGGGGATCTCG }\end{array}$ & $-1,959--1,938$ & \multirow[t]{2}{*}{ Promoter } & \multirow[t]{2}{*}{327} & \multirow[t]{2}{*}{$58^{\circ} \mathrm{C}$} \\
\hline AP2PUR & 5'-TCATCTGGGGCTTGTTTCTCG & $-1,633--1,653$ & & & \\
\hline AP2PMF & 5'-CACCCAGGAAACCTTAGCCTG & $-1,052--1,032$ & \multirow[t]{2}{*}{ Promoter } & \multirow[t]{2}{*}{313} & \multirow[t]{2}{*}{$66^{\circ} \mathrm{C}$} \\
\hline AP2PMR & 5'-AGACCGGCGAAGTCACTCCAG & $-740--760$ & & & \\
\hline AP2PO-PF & 5'-CAGCTCGGATCGTGGTAGCAG & $-669--649$ & \multirow[t]{2}{*}{ Promoter } & \multirow[t]{2}{*}{261} & \multirow[t]{2}{*}{$58^{\circ} \mathrm{C}$} \\
\hline AP2PO-PR & 5'-CTCTCTACGCCGCGAACTTGC & $-409--429$ & & & \\
\hline AP2PD-PF & 5'-GAGCTCGAGGAAGGTTTTATC & $-478--458$ & \multirow[t]{2}{*}{ Promoter } & \multirow[t]{2}{*}{213} & \multirow[t]{2}{*}{$58^{\circ} \mathrm{C}$} \\
\hline AP2PD-PR & 5'-GAGATCTCCСТCTAATGGTAG & $-266--286$ & & & \\
\hline AP2STRPF & 5'-CTACCATTAGAGGGAGATCTC & $-286--266$ & \multirow{2}{*}{$\begin{array}{l}\text { Promoter and } \\
\text { partial exon } 1\end{array}$} & \multirow[t]{2}{*}{322} & \multirow[t]{2}{*}{$58^{\circ} \mathrm{C}$} \\
\hline AP2STRPR & 5'-CTCGTACTTGATATTATCCGTC & $36-15$ & & & \\
\hline AP2STRPF & 5'-CTACCATTAGAGGGAGATCTC & $-286--266$ & \multirow[t]{2}{*}{ Exon 1} & \multirow[t]{2}{*}{366} & \multirow[t]{2}{*}{$58^{\circ} \mathrm{C}$} \\
\hline AP2EX1PR & $5^{\prime}$-TGACCGCA+CGGATGATCGAG & $80-61$ & & & \\
\hline AP2EX2UF & 5'-CAACGGGAACGGGCCATTTCC & $4,438-4,458$ & \multirow{2}{*}{$\begin{array}{l}\text { Upstream region } \\
\text { of exon } 2\end{array}$} & \multirow[t]{2}{*}{324} & \multirow[t]{2}{*}{$64^{\circ} \mathrm{C}$} \\
\hline AP2EX2UR & 5'-TGCAGGGGGTTCAGGCTGTAG & $4,761-4,741$ & & & \\
\hline $\mathrm{AP} 2 \mathrm{EX} 2 \mathrm{DF}$ & 5'-GTCGCAAGATCCTTACTCCCAC & $4,708-4,729$ & \multirow{2}{*}{$\begin{array}{l}\text { Downstream } \\
\text { region of exon } 2\end{array}$} & \multirow[t]{2}{*}{311} & \multirow[t]{2}{*}{$62^{\circ} \mathrm{C}$} \\
\hline AP2EX2DR & 5'-CTGTGTTCCCTCGGCTGGTTG & $5,018-4,998$ & & & \\
\hline AP2EX3PF & 5'-CACTTACATCCATGTGTATC & $8,011-8,030$ & \multirow[t]{2}{*}{ Exon 3} & \multirow[t]{2}{*}{216} & \multirow[t]{2}{*}{$58^{\circ} \mathrm{C}$} \\
\hline AP2EX3PR & 5'-TGCCTATCTATTTGCTAATTC & $8,226-8,206$ & & & \\
\hline AP2EX4PF & 5'-GACGCCCAACACGCGGCCTC & $10,098-10,117$ & \multirow[t]{2}{*}{ Exon 4} & \multirow[t]{2}{*}{348} & \multirow[t]{2}{*}{$71^{\circ} \mathrm{C}$} \\
\hline AP2EX4PR & 5'-GTTTCGGTCGCCGCCACCGC & $10,445-10,426$ & & & \\
\hline AP2EX5PF & 5'-GTGGTGCAGAGAACCCAATG & $12,273-12,292$ & \multirow[t]{2}{*}{ Exon 5} & 212 & $58^{\circ} \mathrm{C}$ \\
\hline AP2EX5PR & 5'-GAAGTTCCTTCTAGTTAGCAAG & $12,484-12,463$ & & & \\
\hline AP2BEX5F & 5'-CGTTACCCTGCTCACATCAC & $12,421-12,440$ & AP-2B-specific & 307 & $58^{\circ} \mathrm{C}$ \\
\hline AP2BEX5R & 5'-GGAGAATGTGCAGTTCTTAAAC & $12,727-12,706$ & region & & \\
\hline AP2EX6PF & 5'-CACTCTTCATTCTCTCGCAC & $14,259-14,278$ & Exon 6 & 251 & $58^{\circ} \mathrm{C}$ \\
\hline AP2EX6PR & 5'-TTTGGTTTCTCTTTCTCTTGAC & $14,509-14,481$ & & & \\
\hline AP2EX7UF & 5'-CTACTAGTGCTGCCCATAGTG & $16,041-16,061$ & Upstream region & 278 & $62^{\circ} \mathrm{C}$ \\
\hline AP2EX7UR & 5'-TGAGGTACATTTTGTCCATGGC & $16,318-16,297$ & of exon 7 & & \\
\hline AP2EX7DF & 5'-TCACGGCCCTGCAGAACTATC & $16,259-16,279$ & Downstream & 215 & $62^{\circ} \mathrm{C}$ \\
\hline AP2EX7DR & 5'-GCTGATCCCGGAGCTGTCAC & $16,473-16,454$ & region of exon 7 & & \\
\hline
\end{tabular}

PCR, Polymerase chain reaction

Significant differences in genotypic frequencies between patients and controls were analyzed using the $\chi^{2}$ test $(2 \times 3$ table) for independence at a significance level of 0.05 (twotailed). Significant differences in allelic frequencies between patients and controls were analyzed by Fisher's exact test $(2 \times 2$ table $)$. Bonferroni correction for multiple comparisons was carried out to exclude type I error. Analysis of linkage disequilibrium was performed with an Associate program (version 2.32) in the Linkage Utility programs (Terwilliger and Ott 1994).

\section{Results}

Three variants in the promoter region of the $A P-2$ gene were identified by SSCP analysis, followed by sequencing. The first variant that showed as an altered SSCP banding pattern was characterized by a single base pair substitution $(\mathrm{G} \rightarrow \mathrm{C})$ at nucleotide position -90 by sequencing. The presence of a $-90 \mathrm{G} \rightarrow \mathrm{C}$ nucleotide substitution was confirmed by RFLP analysis using Msp I. Figure 1 shows the SSCP analysis, sequencing, and RFLP analysis for the $-90 \mathrm{G} \rightarrow \mathrm{C}$ variant. The second variant was characterized by a single base pair substitution $(\mathrm{G} \rightarrow \mathrm{T})$ at nucleotide position -803 (Fig. 2). No restriction enzyme was commercially available to allow RFLP analysis of the $-803 \mathrm{G} \rightarrow \mathrm{T}$ variant. The third variant was characterized by a single base pair substitution $(\mathrm{G} \rightarrow \mathrm{A})$ at nucleotide position -1769 , which was found as a heterozygote in a single control sample. However, no variant was identified in the whole coding region, or in any of the exonintron boundaries of the $A P-2$ gene.

Contrary to previously published sequence data (Bauer et al. 1994), inconsistencies, i.e., the $C$ nucleotide insertion between nucleotides -89 and -88 (see Fig. 1), the G nucleotide insertion between nucleotides -807 and -806 , and the $\mathrm{G}$ instead of $\mathrm{C}$ at nucleotide position -808 (see Fig. 2) were observed in all samples tested.

Table 2 indicates polymorphic status between the -90 and -803 loci in schizophrenics and controls. The polymorphic status of each sample at these two loci was almost identical, and suggested that strong, but not complete, linkage disequilibrium had occurred between the $-90 \mathrm{G}$ and $-803 \mathrm{G}$ alleles, and between the $-90 \mathrm{C}$ and $-803 \mathrm{~T}$ alleles.

Table 3 shows the genotypic and allelic frequencies at the AP-2 -90 and -803 loci in schizophrenics, including subtypes and course specifiers, and controls. Deviation from Hardy-Weinberg equilibrium was tested for each of the groups. Evidence of significant deviation was obtained in schizophrenics with a continuous course $\left(\chi^{2}=4.05\right.$; degree of freedom $[\mathrm{df}]=1 ; P=0.044)$. This probably results from the relatively small population samples. No significant deviation was observed in other groups. No significant differences in genotypic and allelic frequencies at the -90 and 


\section{SSCP analysis}
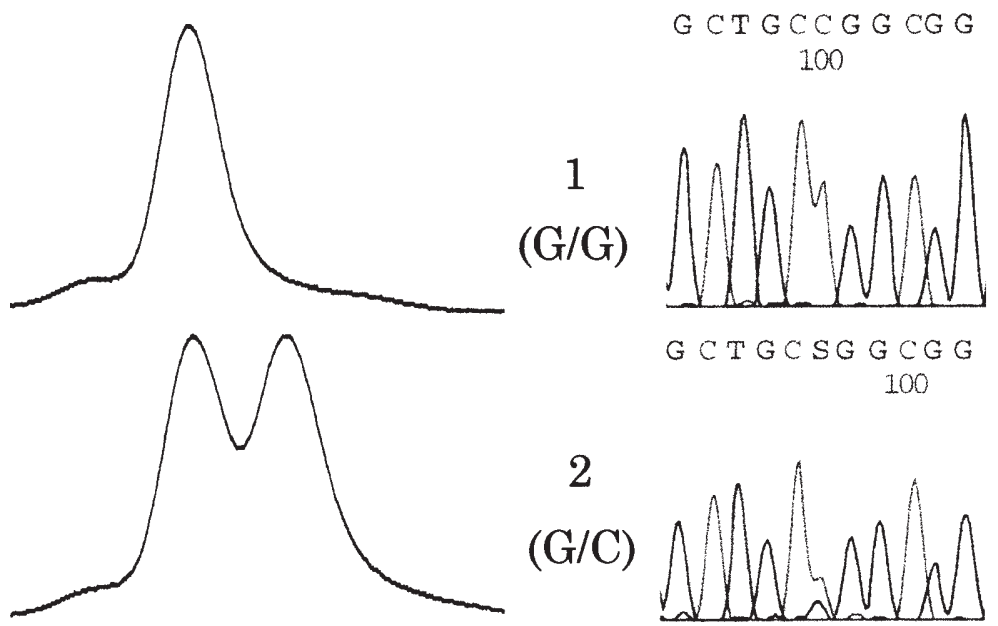

GCT GCSG GCG

100

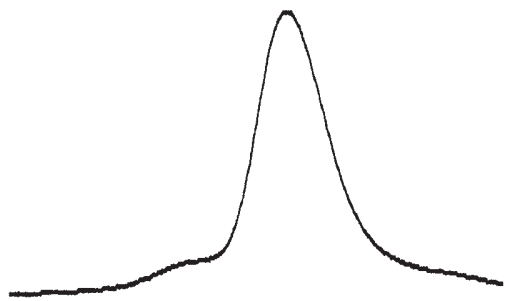

2
$(\mathrm{G} / \mathrm{C})$

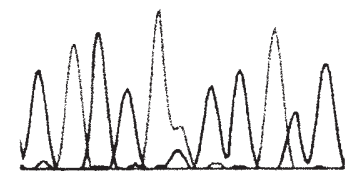

G CT C C G G CG G 100

3

$(\mathrm{C} / \mathrm{C})$

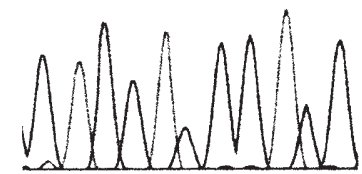

RFLP analysis

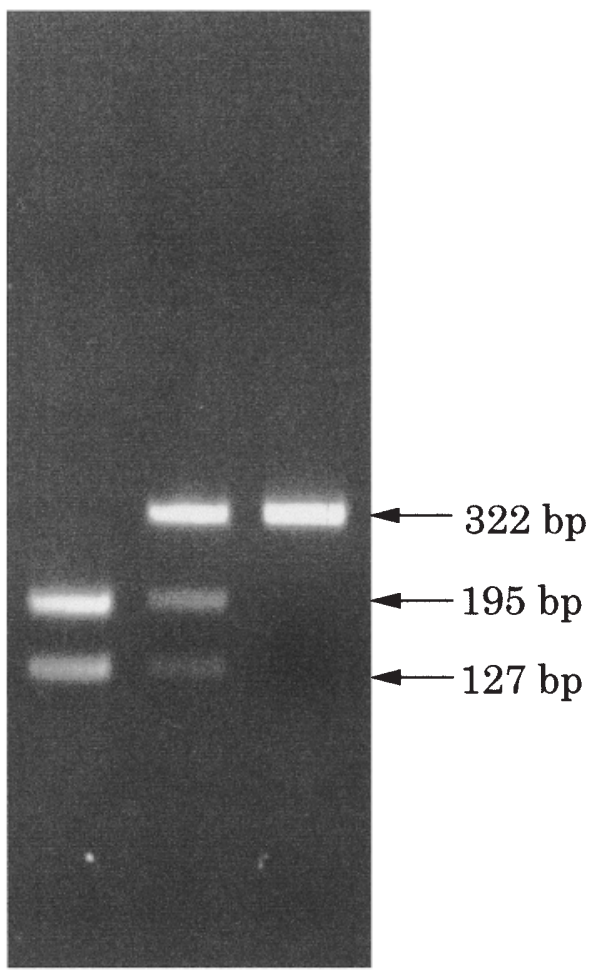

$1 \quad 2 \quad 3$
Fig. 1. Single-strand conformational polymorphism (SSCP) analysis, direct sequencing, and restriction fragment-length polymorphism $(R F L P)$ analysis of polymerase chain reaction (PCR) products generated using the AP2STRPF and AP2STRPR primer sets. Shown here is reverse sequencing. A single base pair substitution $(\mathrm{G} \rightarrow \mathrm{C})$ at nucleotide position -90 was detected by sequencing $(S=C$ or $\mathrm{G})$. A C

Table 2. Polymorphic status between the -90 and -803 loci in a schizophrenics and $\mathbf{b}$ controls

\begin{tabular}{lrrrr}
\hline-803 & GG & GC & CC & Total \\
\hline GG & & & & \\
GT & 35 & 1 & 0 & 36 \\
TT & 0 & 38 & 1 & 39 \\
Total & 0 & 0 & 12 & 12 \\
& 35 & 39 & 13 & 87 \\
\hline
\end{tabular}

Delta value $=0.2268 ; \chi^{2}=157.259 ;$ degree of freedom $(\mathrm{df})=1$; $P<0.000001$

b

\begin{tabular}{lrrrrr}
\hline GG & -90 & GG & GC & CC & Total \\
\hline GT & 43 & 1 & 0 & 44 \\
TT & 0 & 49 & 0 & 49 \\
Total & 0 & 1 & 6 & 7 \\
\hline
\end{tabular}

Delta value $=0.2107 ; \chi^{2}=159.198 ; \mathrm{df}=1 ; P<0.000001$ nucleotide insertion between nucleotides -89 and -88 was observed in all samples, contrary to previously published sequence data. In the absence of the mutated site, the 322-bp PCR product was cut by $M s p$ I, producing fragments of 195 and 127 bp. Samples 1, 2, and 3 indicate homozygous $(\mathrm{G} / \mathrm{G})$, heterozygous $(\mathrm{G} / \mathrm{C})$, and homozygous $(\mathrm{C} / \mathrm{C})-90$ locus genotypes, respectively

-803 loci were found between patients and controls. The limited size of the patient sample presented a problem for the statistical analysis. Because the frequency of the expected values smaller than 5 was more than $20 \%$, a complete anaysis of each of the individual subtypes and course specifiers within the patient group was not possible. For the purpose of the analysis, therefore the catatonic subtype and the undifferentiated subtype were grouped into a single category. The same was done for the patients in the single episode and other or unspecified pattern. No association was observed between the genotypic and allelic distributions, and the subtypes of schizophrenia. In regard to course specifiers, there was a significant difference in the distribution of genotypes at the -90 locus between patients with an episodic course and controls $\left(\chi^{2}=9.56 ; \mathrm{df}=2 ; P=0.008\right.$; and $P=0.016$ after Bonferroni correction). There was also a significant difference in the distribution of genotypes at the -803 locus between patients with the episodic course and controls $\left(\chi^{2}=6.60 ; \mathrm{df}=2 ; P=0.037\right)$, but the observed $P$ value was 0.074 after Bonferroni correction. No significant differences in allelic frequencies at the loci were found between the groups. 
Fig. 2. SSCP analysis and direct sequencing of PCR products generated using the AP2PMF and AP2PMR primer sets. A single base pair substitution $(\mathrm{G} \rightarrow \mathrm{T})$ at nucleotide position -803 was detected by sequencing $(\mathrm{K}=\mathrm{G}$ or $\mathrm{T})$. Samples 1,2 , and 3 indicate homozygous $(\mathrm{G} / \mathrm{G})$, heterozygous $(\mathrm{G} / \mathrm{T})$, and homozygous $(\mathrm{T} /$ T) -803 locus genotypes, respectively. A $G$ nucleotide insertion between nucleotides -807 and -806 , and a G instead of $\mathrm{C}$ at nucleotide position -808 were observed in all samples, contrary to previously published sequence data

\section{SSCP analysis}

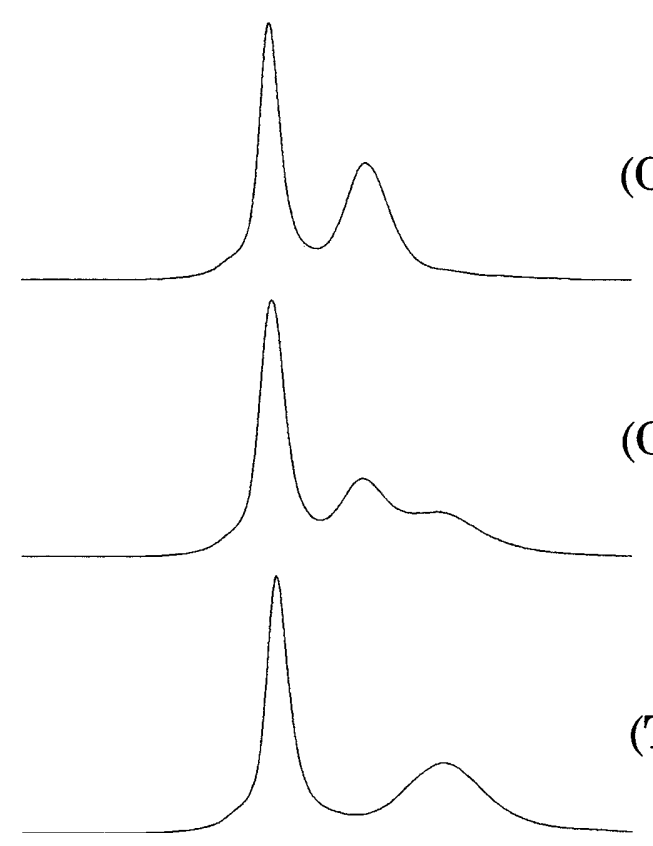

\section{Sequencing}

G AG G G G G TG C T G 220

1

$(\mathrm{G} / \mathrm{G})$

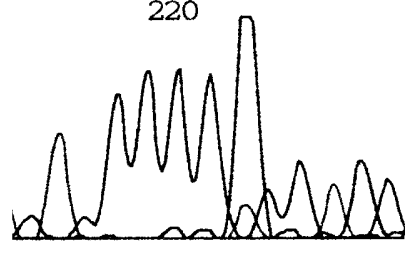

GAGGGG K TGG C TG 220

2

$(\mathrm{G} / \mathrm{T})$

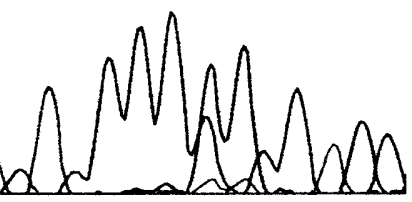

GAGGGG T TG G C T G

3

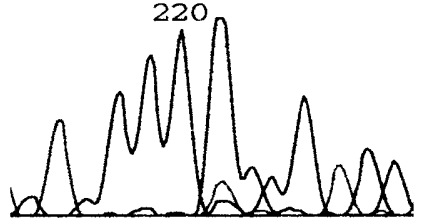

Table 3. Genotypic and allelic frequencies at the AP-2 -90 and -803 loci in schizophrenics, including subtypes and course specifiers (American Psychiatric Association 1994), and controls

\begin{tabular}{|c|c|c|c|c|c|c|c|c|c|c|c|}
\hline & \multirow[b]{3}{*}{ Subjects $(n)$} & \multicolumn{5}{|c|}{-90 locus } & \multicolumn{5}{|c|}{-803 locus } \\
\hline & & \multicolumn{3}{|c|}{ Genotypes } & \multicolumn{2}{|c|}{ Alleles } & \multicolumn{3}{|c|}{ Genotypes } & \multicolumn{2}{|c|}{ Alleles } \\
\hline & & $\begin{array}{l}\mathrm{GG} \\
(\%)\end{array}$ & $\begin{array}{l}\mathrm{GC} \\
(\%)\end{array}$ & $\begin{array}{l}\mathrm{CC} \\
(\%)\end{array}$ & $\begin{array}{l}\mathrm{G} \\
(\%)\end{array}$ & $\begin{array}{l}\mathrm{C} \\
(\%)\end{array}$ & $\begin{array}{l}\text { GG } \\
(\%)\end{array}$ & $\begin{array}{l}\text { GT } \\
(\%)\end{array}$ & $\begin{array}{l}\mathrm{TT} \\
(\%)\end{array}$ & $\begin{array}{l}\mathrm{G} \\
(\%)\end{array}$ & $\begin{array}{l}\mathrm{T} \\
(\%)\end{array}$ \\
\hline \multirow[t]{11}{*}{ Schizophrenics (87) } & & $35(40)$ & $39(45)$ & $13(15)$ & $109(63)$ & $65(37)$ & $36(41)$ & $39(45)$ & $12(14)$ & $111(64)$ & $63(36)$ \\
\hline & & \multicolumn{3}{|c|}{$\chi^{2}=4.12, P=0.128$} & \multicolumn{2}{|c|}{$P=0.275$} & \multicolumn{3}{|c|}{$\chi^{2}=2.36, P=0.307$} & \multicolumn{2}{|c|}{$P=0.381$} \\
\hline & Paranoid type (18) & $11(61)$ & $5(28)$ & $2(11)$ & \multirow{2}{*}{\multicolumn{2}{|c|}{$P=0.556$}} & $11(61)$ & $5(28)$ & $2(11)$ & $27(75)$ & $9(25)$ \\
\hline & & \multicolumn{3}{|c|}{$\chi^{2}=3.41, P=0.181$} & & & \multicolumn{3}{|c|}{$\chi^{2}=2.80, P=0.247$} & \multicolumn{2}{|c|}{$P=0.556$} \\
\hline & Disorganized type (28) & $7(25)$ & $16(57)$ & $5(18)$ & $30(54)$ & $26(46)$ & $7(25)$ & $16(57)$ & $5(18)$ & $30(54)$ & $26(46)$ \\
\hline & & \multicolumn{3}{|c|}{$\chi^{2}=5.55, P=0.062$} & \multicolumn{2}{|c|}{$P=0.056$} & \multicolumn{3}{|c|}{$\chi^{2}=5.02, P=0.081$} & \multicolumn{2}{|c|}{$P=0.056$} \\
\hline & \multirow{2}{*}{$\begin{array}{l}\text { Catatonic type and } \\
\text { undifferentiated type (13) } \\
\text { Residual type (28) }\end{array}$} & $\begin{array}{l}5(39) \\
\chi^{2}=\end{array}$ & $\chi^{2}=1.54, P=0.463$ & $\begin{array}{l}2(15) \\
0.463\end{array}$ & \multicolumn{2}{|c|}{$P=0.507$} & $\begin{array}{l}6(46) \\
\chi^{2}=\end{array}$ & $\chi^{2}=1.30, P=0.523$ & $\begin{array}{l}2(15) \\
0.523\end{array}$ & $\begin{array}{l}17(65) \\
\quad P=(\end{array}$ & $\begin{array}{l}9(35) \\
.824\end{array}$ \\
\hline & & $12\left(\begin{array}{l}(43) \\
x^{2}\end{array}\right.$ & \multicolumn{2}{|c|}{$\chi^{2}=2.22, P=0.330$} & \multicolumn{2}{|c|}{$P=0.628$} & \multicolumn{3}{|c|}{$\chi^{2}=0.423, P=0.810$} & $\begin{array}{l}37(66) \\
\quad P=(\end{array}$ & $\begin{array}{l}19(34) \\
.748\end{array}$ \\
\hline & Episodic (53) & \multicolumn{3}{|c|}{$\chi^{2}=9.56, P=0.008^{*}$} & \multicolumn{2}{|c|}{$P=0.101$} & \multicolumn{3}{|c|}{$\chi^{2}=6.60, P=0.037^{* *}$} & $\begin{array}{c}64(60) \\
P=\end{array}$ & $\begin{array}{l}42(40) \\
166\end{array}$ \\
\hline & Continuous (19) & & $\chi^{2}=1.73, P=0.421$ & $\begin{array}{c}0(0) \\
0.421\end{array}$ & \multicolumn{2}{|c|}{$P=1.000$} & \multicolumn{3}{|c|}{$\chi^{2}=2.15, P=0.342$} & $\begin{array}{l}26(68) \\
\quad P=1\end{array}$ & $\begin{array}{l}12(32) \\
.000\end{array}$ \\
\hline & $\begin{array}{l}\text { Single episode and other or } \\
\text { unspecified pattern (15) }\end{array}$ & $\begin{array}{l}7(47) \\
\chi^{2}=\end{array}$ & $\begin{array}{r}7(47) \\
0.098, P=\end{array}$ & $\begin{array}{l}1(6) \\
0.952\end{array}$ & $\begin{array}{rl}21 & (70) \\
P & P=\end{array}$ & $\begin{array}{l}9(30) \\
.000\end{array}$ & $\begin{array}{l}7(47) \\
\chi^{2}=\end{array}$ & $\begin{array}{r}7(47) \\
.038, P=\end{array}$ & $\begin{array}{l}1(6) \\
0.981\end{array}$ & $\begin{aligned} & 21(70) \\
& \quad P=1\end{aligned}$ & $\begin{array}{l}9(30) \\
.000\end{array}$ \\
\hline Controls (100) & & $43(43)$ & $51(51)$ & $6(6)$ & $137(69)$ & $63(31)$ & $44(44)$ & $49(49)$ & $7(7)$ & $137(69)$ & $63(31)$ \\
\hline
\end{tabular}

$\mathrm{P}$ values after the Bonferroni correction were * $P=0.016 ; * * P=0.074$

\section{Discussion}

Three polymorphisms were found in the promoter region, two relatively common $(-90 \mathrm{G} \rightarrow \mathrm{C},-803 \mathrm{G} \rightarrow \mathrm{T})$ and one rare $(-1769 \mathrm{G} \rightarrow \mathrm{A})$. Polymorphic status at both loci suggested strong linkage disequilibrium between the -90 and
-803 loci. This may be the first report of nucleotide sequence variants of the human $A P-2$ gene. However, none of the three nucleotide variants reported in this study corresponded to the motifs relating to transcriptional regulation of the AP-2 gene. This suggests that the variants are not likely to have functional influence on the transcriptional activity of the $A P-2$ gene. 
The whole coding region containing the AP-2B specific region, and all of the exon-intron boundaries of the $A P-2$ gene were analyzed in order to identify genetic variations that may lead to the alteration of protein function. However, no variant was detected in these coding regions. This suggests that the sequence in the coding region of the $A P-2$ gene may be well conserved, or that a severe phenotype may be expected from the alteration of protein function due to mutations of the $A P-2$ gene, as is seen for the CREB binding protein (CBP) in Rubinstein-Taybi syndrome (Petrij et al. 1995). However, it is possible that we missed a variant, as the sensitivity of SSCP analysis is not believed to be 100\% (Hayashi 1992; Jordanova et al. 1997).

No significant differences in genotypic and allelic frequencies at the -90 and -803 loci were found between patients and controls. Significant differences in the distribution of genotypes at the -90 and -803 loci were observed in patients with an episodic course compared with controls, although no significant differences in allelic frequencies were observed between the groups. The observed $P$ value for the distribution of genotypes in patients with an episodic course showed siginificance with regard to the -90 locus after the Bonferroni correction for multiple comparisons. In contrast, a type I error may be involved in the positive result of the -803 locus, since the observed $\mathrm{P}$ value showed no significance after the Bonferroni correction. Our small number of samples may have led to a discrepancy between the results of statistical analysis of the -90 and -803 loci with strong linkage disequilibrium and to a discrepancy between the results of statistical analysis of genotypic and allelic frequencies at the -90 locus. A substantially larger sample size may clarify these inconsistencies.

Recent studies have suggested that functional polymorphisms in the promoter regions of genes expressed in the brain are involved in the susceptibility to neuropsychiatric disorders, including schizophrenia, affective disorder, panic disorder, and Alzheimer's disease (Collier et al. 1996; Arinami et al. 1997; Artiga et al. 1998; Ohara et al. 1998; Wang et al. 1998). Considering the many genes that contain AP-2 binding sites, the widespread roles of AP-2, and the profound developmental abnormalities observed in AP-2 null mice (Schorle et al. 1996; Zhang et al. 1996), it is possible that variants located not in the coding region but in the promoter region of the $A P-2$ gene, which may exert a subtle effect on AP-2 protein expression, could be involved in the development of particular schizophrenic phenotypes.

In conclusion, our data provided no direct evidence of an association between schizophrenia and the polymorphisms of the $A P-2$ gene, although the positive result at the -90 locus in schizophrenics with an episodic course is potentially interesting. Therefore, a follow-up study with a large sample size will be necessary to determine whether there is significant statistical evidence for involvement of the $A P-2$ gene in susceptibility to schizophrenia. The polymorphic site did not correspond to any putative consensus sequences of transcriptional factors reported previously, but we can not exclude the possibility that this polymorphic site may be involved in the binding cis-elements of unknown transcriptional factors. Further detailed analysis will be necessary to support the notion that the transversion from $-90 \mathrm{G}$ to $\mathrm{C}$ changes the transcriptional activity of the $A P-2$ gene. These analyses are being carried out in our laboratory.

\section{References}

American Psychiatric Association (1994) Diagnostic and statistical manual of mental disorders, 4th edn. American Psychiatric Association, Washington, DC, pp 273-315

Antonarakis SE, Blouin JL, Pulver AE, Wolyniec P, Lasseter VK, Nestadt G, Kasch L, Babb R, Kazazian HH, Dombroski B, Kimberland M, Ott J, Housman D, Karayiorgou M, Maclean CJ (1995) Schizophrenia susceptibility and chromosome 6p24-22. Nat Genet 11:235-236

Arinami T, Gao M, Hamaguchi H, Toru M (1997) A functional polymorphism in the promoter region of the dopamine $\mathrm{D} 2$ receptor gene is associated with schizophrenia. Hum Mol Genet 6:577-582

Artiga MJ, Bullido MJ, Frank A, Sastre I, Recuero M, García MA, Lendon CL, Han SW, Morris JC, Vázquez J, Goate A, Valdivieso F (1998) Risk for Alzheimer's disease correlates with transcriptional activity of the APOE gene. Hum Mol Genet 7:1887-1892

Baeuerle PA (1991) The inducible transcription activator NF-кB: regulation by distinct protein subunits. Biochim Biophys Acta 1072:63-80

Bauer R, Imhof A, Pscherer A, Kopp H, Moser M, Seegers S, Kerscher M, Tainsky MA, Hofstaedter F, Buettner R (1994) The genomic structure of the human AP-2 transcription factor. Nucleic Acids Res 22:1413-1420

Collier DA, Stöber G, Li T, Heils A, Catalano M, Di Bella D, Arranz MJ, Murray RM, Vallada HP, Bengel D, Müller CR, Roberts GW, Smeraldi E, Kirov G, Sham P, Lesch KP (1996) A novel functional polymorphism within the promoter of the serotonin transporter gene: possible role in susceptibility to affective disorders. Mol Psychiatry 1:453-460

Creaser PC, D'Argenio DA, Williams T (1996) Comparative and functional analysis of the AP2 promoter indicates that conserved octamer and initiator elements are critical for activity. Nucleic Acids Res 24:2597-2605

Davies AF, Stephens RJ, Olavesen MG, Heather L, Dixon MJ, Magee A, Flinter F, Ragoussis J (1995) Evidence of a locus for orofacial clefting on human chromosome 6p24 and STS content map of the region. Hum Mol Genet 4:121-128

Ebert SN, Ficklin MB, Her S, Siddall BJ, Bell RA, Ganguly K, Morita K, Wong DL (1998) Glucocorticoid-dependent action of neural crest factor AP-2: stimulation of phenylethanolamine $N$-methyltransferase gene expression. J Neurochem 70:2286-2295

Fornasari D, Battaglioli E, Flora A, Terzano S, Clementi F (1997) Structural and functional characterization of the human $\alpha 3$ nicotinic subunit gene promoter. Mol Pharmacol 51250-51261

Gottesman II (1994) Schizophrenia epigenesis: past, present, and future. Acta Psychiatr Scand 90 (Suppl 384):26-33

Hayashi K (1992) PCR-SSCP: a method for detection of mutations. Genet Anal Tech Appl 9:73-79

Hyman SE, Comb M, Pearlberg J, Goodman HM (1989) An AP-2 element acts synergistically with the cyclic AMP- and phorbol esterinducible enhancer of the human proenkephalin gene. Mol Cell Biol 9:321-324

Imagawa M, Chiu R, Karin M (1987) Transcription factor AP-2 mediates induction by two different signal-transduction pathways: protein kinase C and cAMP. Cell 51:251-260

Jordanova A, Kalaydjieva L, Savov A, Claustres M, Schwarz M, Estivill X, Angelicheva D, Haworth A, Casals T, Kremensky I (1997) SSCP analysis: a blind sensitivity trial. Hum Mutat 10:65-70

Kawanishi Y, Harada S, Tachikawa H, Okubo T, Shiraishi H (1998) Novel mutations in the promoter and coding region of the human 5$\mathrm{HT}_{1 \mathrm{~A}}$ receptor gene and association analysis in schizophrenia. Am J Med Genet 81:434-439

Kim HS, Seo H, Yang C, Brunet JF, Kim KS (1998) Noradrenergicspecific transcription of the dopamine $\beta$-hydroxylase gene requires synergy of multiple cis-acting elements including at least two Phox2a-binding sites. J Neurosci 18:8247-8260

Leask A, Byrne C, Fuchs E (1991) Transcription factor AP2 and its 
role in epidermal-specific gene expression. Proc Natl Acad Sci USA 88:7948-7952

Minowa MT, Minowa T, Monsma FJ Jr, Sibley DR, Mouradian MM (1992) Characterization of the $5^{\prime}$ flanking region of the human $\mathrm{D}_{1 \mathrm{~A}}$ dopamine receptor gene. Proc Natl Acad Sci USA 89:3045-3049

Mitchell PJ, Timmons PM, Hébert JM, Rigby PW, Tjian R (1991) Transcription factor AP-2 is expressed in neural crest cell lineages during mouse embryogenesis. Genes Dev 5:105-119

Moises HW, Yang L, Kristbjarnarson H, Wiese C, Byerley W, Macciardi F, Arolt V, Blackwood D, Liu X, Sjögren B, Aschauer HN, Hwu HG, Jang K, Livesley WJ, Kennedy JL, Zoega T, Ivarsson O, Bui MT, Yu MH, Havsteen B, Commenges D, Weissenbach J, Schwinger E, Gottesman II, Pakstis AJ, Wetterberg L, Kidd KK, Helgason T (1995) An international two-stage genome-wide search for schizophrenia susceptibility genes. Nat Genet 11:321-324

Morris-Rosendahl DJ, Burgert E, Uyanik G, Mayerova A, Duval F, Macher JP, Crocq MA (1997) Analysis of the CAG repeats in the SCA1 and B37 genes in schizophrenic and bipolar I disorder patients: tentative association between B37 and schizophrenia. Am J Med Genet 74:324-330

Ohara K, Nagai M, Tani K, Nakamura Y, Ino A, Ohara K (1998) Functional polymorphism of $-141 \mathrm{C}$ Ins/Del in the dopamine $\mathrm{D}_{2}$ receptor gene promoter and schizophrenia. Psychiatry Res 81:117123

Okawa Y, Adachi A, Ino M, Nagumo S, Matsui H (1998) Further characterization of the $5^{\prime}$-flanking promoter region of the human $\beta_{1^{-}}$ adrenergic receptor gene. Psychiatry Clin Neurosci 52:453-458

Olavesen MG, Davies AF, Broxholme SJ, Wixon JL, Senger G, Nizetic D, Campbell RD, Ragoussis J (1995) An integrated map of human chromosome 6p23. Genome Res 5:342-358

Olavesen MG, Bentley E, Mason RV, Stephens RJ, Ragoussis J (1997) Fine mapping of 39 ESTs on human chromosome 6p23-p25. Genomics 46:303-306

Pennypacker KR, Fuldner R, Xu R, Hernandez H, Dawbarn D, Mehta N, Perez-Tur J, Baker M, Hutton M (1998) Cloning and characterization of the presenilin-2 gene promoter. Brain Res Mol Brain Res 56:57-65

Petersohn D, Schoch S, Brinkmann DR, Thiel G (1995) The human synapsin II gene promoter. Possible role for the transcription factor zif268/egr-1, polyoma enhancer activator 3, and AP2. J Biol Chem 270:24361-24369
Petrij F, Giles RH, Dauwerse HG, Saris JJ, Hennekam RC, Masuno M, Tommerup N, van Ommen GJ, Goodman RH, Peters DJ, Breuning MH (1995) Rubinstein-Taybi syndrome caused by mutations in the transcriptional co-activator CBP. Nature 376:348-351

Schizophrenia Linkage Collaborative Group for Chromosomes 3, 6 and 8 (1996) Additional support for schizophrenia linkage on chromosomes 6 and 8: a multicenter study. Am J Med Genet 67:580-594

Schorle H, Meier P, Buchert M, Jaenisch R, Mitchell PJ (1996) Transcription factor AP-2 essential for cranial closure and craniofacial development. Nature 381:235-238

Schwab SG, Albus M, Hallmayer J, Hönig S, Borrmann M, Lichtermann D, Ebstein RP, Ackenheil M, Lerer B, Risch N, Maier W, Wildenauer DB (1995) Evaluation of a susceptibility gene for schizophrenia on chromosome $6 p$ by multipoint affected sib-pair linkage analysis. Nat Genet 11:325-327

Straub RE, MacLean CJ, O’Neill FA, Burke J, Murphy B, Duke F, Shinkwin R, Webb BT, Zhang J, Walsh D, Kendler KS (1995) A potential vulnerability locus for schizophrenia on chromosome 6p2422: evidence for genetic heterogeneity. Nat Genet 11:287-293

Terwilliger JD, Ott J (1994) Handbook of human genetic linkage. The Johns Hopkins University Press, Baltimore, pp 188-198

Wang S, Sun CE, Walczak CA, Ziegle JS, Kipps BR, Goldin LR, Diehl SR (1995) Evidence for a susceptibility locus for schizophrenia on chromosome 6pter-p22. Nat Genet 10:41-46

Wang S, Detera-Wadleigh SD, Coon H, Sun CE, Goldin LR, Duffy DL, Byerley WF, Gershon ES, Diehl SR (1996) Evidence of linkage disequilibrium between schizophrenia and the SCA1 CAG repeat on chromosome 6p23. Am J Hum Genet 59:731-736

Wang Z, Valdes J, Noyes R, Zoega T, Crowe RR (1998) Possible association of a cholecystokinin promoter polymorphism $\left(\mathrm{CCK}_{-36 \mathrm{CT}}\right)$ with panic disorder. Am J Med Genet 81:228-234

Williams T, Tjian R (1991a) Analysis of the DNA-binding and activation properties of the human transcription factor AP-2. Genes Dev 5:670-682

Williams T, Tjian R (1991b) Characterization of a dimerization motif in AP-2 and its function in heterologous DNA-binding proteins. Science 251:1067-1071

Zhang J, Hagopian-Donaldson S, Serbedzija G, Elsemore J, PlehnDujowich D, McMahon AP, Flavell RA, Williams T (1996) Neural tube, skeletal and body wall defects in mice lacking transcription factor AP-2. Nature 381:238-241 